\title{
OUTBREAK OF CLOSTRIDIUM DIFFICILE-
}

\section{ASSOCIATED DIARRHEA DUE TO HYPERVIRULENT STRAIN NAP1/B1/027 IN A DEVELOPING COUNTRY}

\author{
Monge Bonilla, Cecilia ${ }^{1}$; Acuña Feoli, José1; Rodríguez Angulo, Guillermo1; Araya Alegría, \\ Luis $^{1}$; Jara Cordero, Olman ${ }^{1}$; Alvarado Aguilar, Marco ${ }^{1}$ y Quesada Vargas, Jorge ${ }^{1}$. \\ 1 Médico Especialista en Medicina Interna. Departamento de Medicina Interna. Sección de Medicina 4. Hospital San Juan de \\ Dios. San José, Costa Rica.
}

\begin{abstract}
Resumen: Los brotes nosocomiales de las cepas hipervirulenta de Clostridium difficile son un problema importante de salud pública debido a la naturaleza altamente contagiosa y letal de esta enfermedad en el ámbito intra-hospitalario. Afortunadamente, estos casos son raros. Presentamos el reporte y manejo de un brote nosocomial de $C$. difficile por una cepa hipervirulenta en un país en vías de desarrollo. Entre mayo y agosto 2009, 81 casos de diarrea asociada a C. difficile (CDAD) fueron tratados en la unidad de aislamiento del Hospital San Juan de Dios en Costa Rica. El porcentaje de recurrencia fue de 13.6\% y la mortalidad 9.9\%. El uso de antibióticos, severidad del cuadro diarreico, recuento leucocitario y co-morbilidades se asociaron a una alta recurrencia de la enfermedad. Pacientes portadores de insuficiencia cardiaca congestiva, aquellos recibiendo inhibidores de bomba de protones o requiriendo vasopresores durante su hospitalización, presentaron un mayor riesgo de muerte. La edad influenció la duración del cuadro diarreico. La duración también aumentó con el uso de probióticos y vasopresores. Brotes de $C$. difficile u otras enfermedades infecciosas no deben ser más letales en un país en vías de desarrollo. Una respuesta rápida y rigorosa y tratamientos costo efectivos son más relevantes que el acceso a una infraestructura compleja o servicios de soporte avanzados.
\end{abstract}

Palabras clave: Clostridium difficile, diarrea nosocomial, cepa hipervirulenta, Costa Rica Recibido: 17 Julio 2011. Aceptado: 2 Septiembre 2011. Publicado: 14 Octubre 2011. 
Abstract: Nosocomial outbreaks of hypervirulent Clostridium difficile are a very serious public health problem because of the highly infectious and lethal nature of the disease in a hospital environment. Fortunately, they are relatively rare. We provide a report of a $C$. difficile nosocomial outbreak and its management in a developing country. From May to August 2009, 81 cases of $C$. difficile-associated diarrhea (CDAD) were treated in an isolation unit at San Juan de Dios Hospital in Costa Rica. The recurrence rate was $13.6 \%$ and the mortality rate was $9.9 \%$. Antibiotic use, severity of CDAD, and leukocyte count were associated with higher recurrence rates of disease. The number of co-morbidities was also related to a higher rate of recurrence. Patients with chronic heart failure, those receiving treatment with proton pump inhibitors, and those requiring vasopressor treatment during their hospitalization had a higher likelihood of dying. Age influenced the duration of diarrhea. The use of probiotics and vasopressors increased the amount of days with diarrhea. Outbreaks of CDAD and other infectious diseases do not need to be more lethal in a developing country. A rigorous and prompt response and cost-effective treatments are more relevant than access to complex infrastructure or advanced support services.

Key words: Clostridium difficile, nosocomial diarrhea, hypervirulent strain, Costa Rica

\section{INTRODUCTION}

Clostridium difficile (C. difficile) is a Grampositive endospore-forming bacillus capable of causing abdominal cramps, mild to severe diarrhea, and colitis. It is highly transmissible through the fecal-oral route and can be cultured from clothing, hands, health care equipment, and other surfaces $[1,2,3]$. Since the year 2000, the hypervirulent $C$ difficile strain known as NAP1/B1/027 (i.e., North American pulsed-field type I, restriction endonuclease analysis group B1, PCR ribotype 027) has been identified as the causative agent of $C$. difficile-associated diarrhea (CDAD) outbreaks within hospitals in developed countries $[3,4,5]$. The NAP1/B1/027 strain differs from other $C$. difficile strains in several ways: it is resistant to fluoroquinolones in vitro, it is capable of producing a unique binary toxin, and it produces significantly greater amounts of exotoxins A and B in vitro and for prolonged periods of time [6-10]. NAP1/B1/027 causes CDAD following colonization of the intestinal tract, facilitated by the disruption of normal intestinal flora due to antimicrobial therapy, among other factors. The $C$. difficile exotoxins bind to receptors on intestinal epithelial cells, leading to inflammation and diarrhea. NAP1/B1/027 causes a much more severe disease than other $C$. difficile strains, is more refractory to standard therapy, is more likely to relapse, and, in developed countries, relapses at rates up to $30 \%$ which results in 16-20\% mortality [11]. 


\section{METHODS}

Nosocomial CDAD cases were classified based on acute diarrhea and positive ELISA for exotoxin A in stool. High-risk patients with symptoms suggestive of CDAD were also admitted to the CDAD isolation unit. Patient data collected upon admission to the unit included information on risk factors and co-morbidities. All stool samples of patients in the isolation unit were tested for exotoxin A by ELISA. Proportions and exact binomial confidence limits were used to assess associations of patients' characteristics with recurrence of diarrhea and discharge outcome.

Fisher's exact test assessed statistical significance of the associations accounting for the small numbers in some of the groups.

Single and multivariate linear models estimated the effects of individual or medical history characteristics on the duration of diarrhea.

\section{CDAD patient management}

A management protocol was developed by the attending internal medicine physicians coordinating the unit, with approval from the chairman of medicine and the head of the hospital. This management protocol ensured that medical care and treatment of CDAD patients was uniform. The protocol included criteria for diagnosis (Figure 1), admission (Figure 2), transfer and discharge (Figure 3), definition of severity, and treatment (Table 1).
Figure 1. Algorithm for the Diagnosis of Clostridium difficile-associated diarrhea

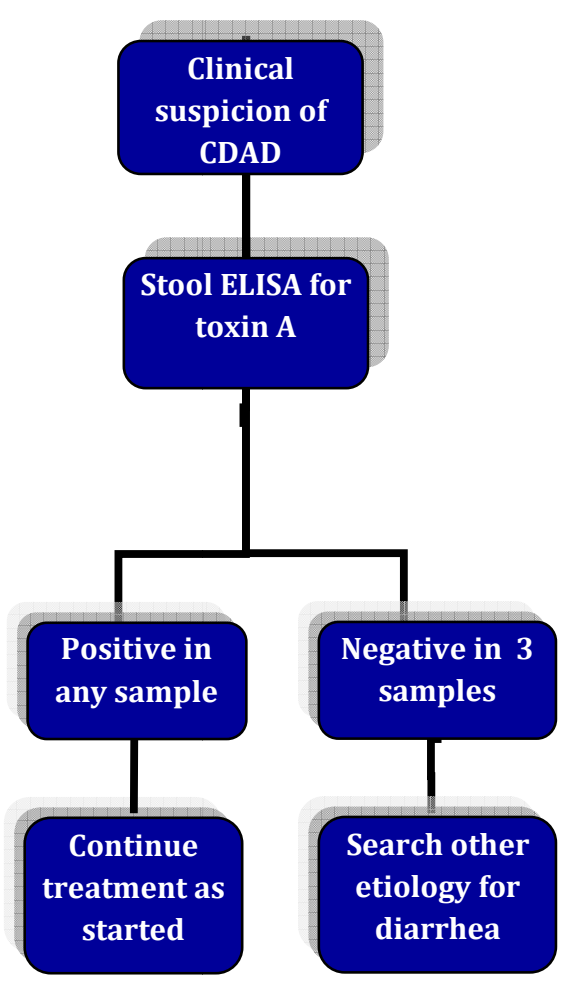

A laboratory-based alert system was instituted. When a stool sample tested positive for C. difficile, the head nurse of the unit was notified so appropriate action could be taken. All hospital personnel were educated on $C$. difficile, its mechanisms of transmission, and the existence of the new isolation unit. 
Figure 2. Protocol for Patient Management of $\boldsymbol{C}$. difficile Isolation Unit in Hospital San Juan de Dios

An eligible case for admission to the unit was defined as any patient with acute diarrhea and positive ELISA for toxin A in stool.

High risk patients with a clinical presentation suggestive of CDAD were treated empirically even in the absence of a positive stool ELISA for toxin A. If the stool ELISA for toxin A remained negative, other diagnostic possibilities were evaluated.

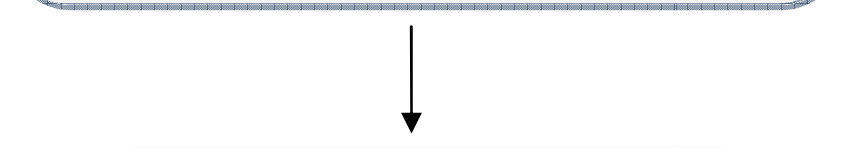

Patients considered at high risk include:

Patients taking the following medications:

-Antibiotics (especially the combination of a cephalosporin and a fluoroquinolone)

-Proton pump inhibitors -Valacyclovir

\section{Patients with the following} characteristics:

-Inflammatory bowel disease

-Multiple or severe

comorbidities

-Advanced age (over 65)

-Immunocompromised or in peripartum

Environment:

-Prolonged hospital stay
Figure 3. Transfer and Discharge Criteria

Resolution Criteria for Transfer out of

Unit in a First Episode:

1. Complete resolution of diarrhea (less than 3 bowel movements in $24 \mathrm{hrs}$ for $72 \mathrm{hrs}$ )

2. Afebrile for $\mathbf{4 8}$ hours

3. Decrease in leucocytosis

4. Absence of clinical signs of pseudo membranous colitis *ELISA for toxin A in stool sample was not a requirement.

\section{Resolution Criteria for Transfer out of Unit in \\ a Recurrence: Complete resolution of diarrhea \\ Criteria that Prompt the Need for Evaluation \\ of Emergency Colectomy: \\ 1-Toxic megacolon \\ 2-Shock needing vasopressors or multiple organ failure}

\section{Criteria for Discharge to Home: \\ 1-Afebrile for 48 hours \\ 2-Complete resolution of diarrhea \\ 3-Improvement in leucocytosis \\ 4-Tolerating oral route \\ 5-Diagnosis for hospital admission resolved or improved \\ * Negative ELISA for toxin was not a criteria for discharge.}


scrubs, hats, and boots. There was a security guard at the entrance of the unit during all hospital shifts to ensure the adherence of these measures and to keep a log of personnel who entered and exited the unit.

Prior to health care workers entering the patient rooms, they would wear disposable gowns (on top of the green scrubs), masks, and gloves; these were used during examination or contact with each individual patient and disposed of after being used with each patient.

Equipment used for patient care, such as stethoscopes, thermometers, and blood pressure cuffs, were thoroughly cleaned between uses, since disposable medical equipment was unavailable.

An integrated infection control program included a strict cleaning schedule every 4 hours with dilute bleach (10\% sodium hypochlorite). All surfaces, beds, mattresses, tables, walls, and windows were cleaned to eliminate $C$. difficile spores, which can remain on surfaces for up to three months $[3,13,15]$.

An antibiotic control program limiting the use of broad-spectrum antibiotics, restricting IV antibiotics, and using short duration treatment protocols was developed by the infectious disease department to try to decrease the pool of susceptible patients.

\section{Statistical methods}

Within the patients treated in the C. difficile isolation unit from May to August we studied the association of patient's characteristics and medical history with recurrence of CDAD, outcome (death, discharge or transfer) and days to resolution of diarrhea.

A total of 81 patients were admitted to the C. difficile isolation unit in the months of May, June,
July, and August 2009. 43 patients were female and 37 male. The mean age of the patient population was 62 years old with a range of 13-91 years. The mean day to resolution of diarrhea was 5 with a range of 1-17 days. A total of 8 of the 81 patients died (9.9\% mortality). The recurrence rate observed was $13.6 \%$ (11 patients recurred at least once).

We used proportions and exact binomial confidence limits to assess associations of patients' characteristics with recurrence of diarrhea and the outcome: transfer, discharge, or death. We were not able to perform multivariate modeling due to low numbers of patients with adverse outcomes (recurrence or death).

Fisher's exact test was used to assess statistical significance of the associations accounting for the small numbers in some of the groups.

Single and multivariate linear models estimated the effects of individual (age, sex) or medical history characteristics (use of antibiotics and other medications, presence of comorbidities, leukocyte count, serum albumin level and severity of diarrhea) on duration of diarrhea. Analysis of residuals assessed the validity of assumptions of the model: linearity of relationships, heteroscedasticity and normality [14]. Since the dependent variable is skewed and represents counts, we used log-days as the outcome in all models. The most parsimonious model was determined using Wald tests of regression coefficients and Akaike Information Criterion (AIC), a measure of goodness of fit that penalizes for including additional predictors in the model. Lowess non-parametric smoother was used to assess the functional form of age [16]. Linear spline with the appropriate knot was used to account for the non-linearity observed in the exploratory analyses [16,17]. 
Reported estimates are based on all available values on the variables with missing data (complete case analyses). Additionally, assuming that values of the predictors are missing at random, multiple imputation of missing data was performed. MCMC data augmentation method was applied using other available measures, to impute the missing values [18]. Sensitivity of results to the model specifications was assessed by including various sets of variables in the imputation models.

Stata 10 (StataCorp. 2007. Stata Statistical Software: Release 10. College Station, TX: StataCorp LP) was used for the analyses and SAS version 9.2 for Windows (SAS Institute, Cary, North Carolina) was used for multiple imputations of missing values and for combining the parameter estimates.

\section{RESULTS}

An increased incidence and associated mortality of CDAD was reported in the internal medicine wards of the Hospital San Juan de Dios during March and April 2009. Samples were sent to the National Microbiology Laboratory of the Canadian Agency for Public Health. The C. difficile strain NAP1 was identified, containing enhanced genes for exotoxins A and B, the binary toxin gene, and deletion of the regulatory gene $t c d C$.

A dedicated $C$. difficile isolation unit was established promptly to manage this nosocomial outbreak. In May 2009-the first month of the CDAD unit - the vast majority of patients were transferred to the unit after having been in the hospital for at least 72 hours, indicating that they were infected after they arrived in the hospital. Over the next three months, 12 patients that had been released from the unit were re-admitted. In August 2009 some CDAD patients were admitted directly from the community, rather than from other parts of the hospital. It was not possible to determine whether these latter patients were exposed to CDAD patients that had been discharged from the hospital, because epidemiological follow-up after discharge was not done, due to lack of funding.

Within the CDAD unit, management practices and patient care were standardized. For statistical purposes, these can be considered as fixed variables. Details of these practices are described in the Methods.

Statistical analyses were performed to evaluate the clinical course of CDAD within the isolation unit in relation to various risk factors. Table 2 details the relationships of various factors and the recurrence of diarrhea. In the univariate analyses, antibiotic use, leukocyte count, and severity of diarrhea were significantly associated with recurrence of diarrhea. Among patients who reported antibiotic use within the previous three months, $21 \%$ had recurrence of diarrhea (95\% CI 11-36) compared to only $6 \%$ of those without antibiotic use (95\% CI 1-20), Fisher's exact p-value $=0.064$. Current antibiotic use was also predictive of recurrence: $23 \%$ (95\% CI 11-38) versus 5\% (95\% CI 1-18) in non-users, Fisher's exact p-value $=0.056$.

None of the reported co-morbidities, such as diabetes mellitus, high blood pressure, chronic obstructive pulmonary disease, congestive heart failure, or chronic kidney disease, were associated with recurrence in the univariate analyses.

The number of co-morbidities, however, was related to recurrence of diarrhea. Twenty-one percent of patients with multiple co-morbidities recurred (95\% CI 11-34), while fourteen percent (1 patient out of 7) with no co-morbidities had a recurrence; Fisher's exact p-value $=0.046$. 
Table 2. Relationship of patient characteristics and the risk of recurrence of diarrhea

\begin{tabular}{|c|c|c|c|c|}
\hline & Recurrence & & Total & \\
\hline & No $(\mathrm{N}=69)$ & $\begin{array}{l}\text { Yes } \\
(\mathrm{N}=12)\end{array}$ & $(\mathrm{N}=\mathbf{8 1})$ & P value \\
\hline Gender, n (\%) & & & & $0.746^{*}$ \\
\hline Female & $38(88 \%)$ & $\begin{array}{r}5 \\
(12 \%)\end{array}$ & 43 & \\
\hline Male & $31(84 \%)$ & $\begin{array}{r}6 \\
(16 \%)\end{array}$ & 37 & \\
\hline Missing & 0 & 1 & 1 & \\
\hline $\begin{array}{l}\text { Proton pump } \\
\text { inhibitor , n (\%) }\end{array}$ & & & & $0.723 *$ \\
\hline No & $48(87 \%)$ & $\begin{array}{r}7 \\
(13 \%)\end{array}$ & 55 & \\
\hline Yes & $19(83 \%)$ & $\begin{array}{r}4 \\
(17 \%)\end{array}$ & 23 & \\
\hline Missing & 2 & 1 & 3 & \\
\hline $\begin{array}{l}\text { Antibiotic use in } \\
\text { last } 3 \text { months, } n \\
\text { (\%) }\end{array}$ & & & $0.064^{*}$ & \\
\hline No & $32(94 \%)$ & $2(6 \%)$ & 34 & \\
\hline Yes & 37 (79\%) & $\begin{array}{r}10 \\
(21 \%)\end{array}$ & 47 & \\
\hline $\begin{array}{l}\text { Current } \\
\text { antibiotic use, n } \\
\text { (\%) }\end{array}$ & & & & $0.056 *$ \\
\hline No & $35(95 \%)$ & $2(5 \%)$ & 37 & \\
\hline Yes & $34(77 \%)$ & $\begin{array}{r}10 \\
(23 \%)\end{array}$ & 44 & \\
\hline $\begin{array}{l}\text { Cephalosporins, } \\
\text { n (\%) }\end{array}$ & & & & $1.000 *$ \\
\hline No & $48(86 \%)$ & $\begin{array}{r}8 \\
(14 \%)\end{array}$ & 56 & \\
\hline Yes & $21(84 \%)$ & $\begin{array}{r}4 \\
(16 \%)\end{array}$ & 25 & \\
\hline $\begin{array}{l}\text { Quinolones, n } \\
\text { (\%) }\end{array}$ & & & & $0.063^{*}$ \\
\hline No & $65(88 \%)$ & $\begin{array}{r}9 \\
(12 \%)\end{array}$ & 74 & \\
\hline Yes & $4(57 \%)$ & $\begin{array}{l}3 \\
(43 \%)\end{array}$ & 7 & \\
\hline
\end{tabular}

\begin{tabular}{|c|c|c|c|c|}
\hline $\begin{array}{l}\text { Penicillins , } n \\
\text { (\%) }\end{array}$ & & & & $0.215^{*}$ \\
\hline No & $65(87 \%)$ & $\begin{array}{r}10 \\
(13 \%)\end{array}$ & 75 & \\
\hline Yes & $4(67 \%)$ & $\begin{array}{r}2 \\
(33 \%)\end{array}$ & 6 & \\
\hline $\begin{array}{l}\text { Clindamycin , } \\
(\%)\end{array}$ & & & & 0.156* \\
\hline No & $66(87 \%)$ & $\begin{array}{r}10 \\
(13 \%)\end{array}$ & 76 & \\
\hline Yes & $3(60 \%)$ & $\begin{array}{r}2 \\
(40 \%)\end{array}$ & 5 & \\
\hline $\begin{array}{l}\text { Carbapenems, n } \\
\text { (\%) }\end{array}$ & & & & 0.056* \\
\hline No & $68(87 \%)$ & $\begin{array}{r}10 \\
(13 \%)\end{array}$ & 78 & \\
\hline Yes & $1(33 \%)$ & $\begin{array}{r}2 \\
(67 \%)\end{array}$ & 3 & \\
\hline $\begin{array}{l}\text { Aminoglycosides } \\
\text {, n (\%) }\end{array}$ & & & & $0.561 *$ \\
\hline No & $65(86 \%)$ & $\begin{array}{r}11 \\
(14 \%)\end{array}$ & 76 & \\
\hline Yes & $4(80 \%)$ & $\begin{array}{r}1 \\
(20 \%)\end{array}$ & 5 & \\
\hline Other, n (\%) & & & & 0.001* \\
\hline No & $53(95 \%)$ & $3(5 \%)$ & 56 & \\
\hline Yes & $16(64 \%)$ & $\begin{array}{r}9 \\
(36 \%)\end{array}$ & 25 & \\
\hline $\begin{array}{l}\text { Comorbidity, n } \\
\text { (\%) }\end{array}$ & & & & $1.000^{*}$ \\
\hline No & $6(86 \%)$ & $\begin{array}{r}1 \\
(14 \%)\end{array}$ & 7 & \\
\hline Yes & $63(85 \%)$ & $\begin{array}{r}11 \\
(15 \%)\end{array}$ & 74 & \\
\hline \multicolumn{5}{|l|}{$\begin{array}{l}\text { Count of } \\
\text { comorbidity , n } \\
\text { (\%) }\end{array}$} \\
\hline $\begin{array}{l}\text { No } \\
\text { comorbidity }\end{array}$ & $6(86 \%)$ & $\begin{array}{r}1 \\
(14 \%)\end{array}$ & 7 & \\
\hline $\begin{array}{l}\text { One } \\
\text { comorbidity }\end{array}$ & $21(100 \%)$ & $0(0 \%)$ & 21 & \\
\hline $\begin{array}{l}\text { More than one } \\
\text { comorbidity }\end{array}$ & $42(79 \%)$ & $\begin{array}{r}11 \\
(21 \%)\end{array}$ & 53 & \\
\hline
\end{tabular}

Revista electrónica publicada por el Departamento de Farmacología de la Escuela de Medicina de la Universidad de Costa Rica, 2060 San José, Costa Rica. ${ }^{\circledR}$ All rights reserved. Licensed under a Creative Commons Unported License. 
Revista Médica de la Universidad de Costa Rica. Volumen 5, número 2, artículo 1

2011

\begin{tabular}{|c|c|c|c|c|}
\hline & Recurrence & & Total & \\
\hline $\begin{array}{l}\text { Diabetes } \\
\text { mellitus, n (\%) }\end{array}$ & & & & $0.324^{*}$ \\
\hline No & 47 (89\%) & $\begin{array}{r}6 \\
(11 \%)\end{array}$ & 53 & \\
\hline Yes & $22(79 \%)$ & $\begin{array}{r}6 \\
(21 \%)\end{array}$ & 28 & \\
\hline HTN, n (\%) & & & & $0.202^{*}$ \\
\hline No & $26(93 \%)$ & $2(7 \%)$ & 28 & \\
\hline Yes & $43(81 \%)$ & \begin{tabular}{|l}
10 \\
$(19 \%)$
\end{tabular} & 53 & \\
\hline $\begin{array}{l}\text { Congestive heart } \\
\text { failure, } n(\%)\end{array}$ & & & & $0.561 *$ \\
\hline No & 65 (86\%) & $\begin{array}{r}11 \\
(14 \%)\end{array}$ & 76 & \\
\hline Yes & $4(80 \%)$ & $\begin{array}{r}1 \\
(20 \%)\end{array}$ & 5 & \\
\hline COPD, n (\%) & & & & $1.000^{*}$ \\
\hline No & $63(85 \%)$ & $\begin{array}{r}11 \\
(15 \%)\end{array}$ & 74 & \\
\hline Yes & $6(86 \%)$ & $\begin{array}{r}1 \\
(14 \%)\end{array}$ & 7 & \\
\hline \multirow{3}{*}{ Missing } & 0 & 1 & 1 & \\
\hline & & & & \\
\hline & No $(\mathrm{N}=69)$ & \begin{tabular}{|l} 
Yes \\
$(\mathrm{N}=12)$
\end{tabular} & $(\mathrm{N}=81)$ & P value \\
\hline $\begin{array}{l}\text { Chronic kidney } \\
\text { disease, n (\%) }\end{array}$ & & & & $1.000^{*}$ \\
\hline No & $59(84 \%)$ & $\begin{array}{r}11 \\
(16 \%)\end{array}$ & 70 & \\
\hline Yes & $10(91 \%)$ & $1(9 \%)$ & 11 & \\
\hline $\begin{array}{l}\text { Use of } \\
\text { probiotics, n (\%) }\end{array}$ & & & & $0.581 *$ \\
\hline No & $51(81 \%)$ & $\begin{array}{r}12 \\
(19 \%)\end{array}$ & 63 & \\
\hline Yes & $6(100 \%)$ & $0(0 \%)$ & 6 & \\
\hline Missing & 12 & 0 & 12 & \\
\hline $\begin{array}{l}\text { Immune } \\
\text { suppression, } n \\
\text { (\%) }\end{array}$ & & & & $0.347^{*}$ \\
\hline No & $6085 \%)$ & $\begin{array}{r}11 \\
(15 \%)\end{array}$ & 71 & \\
\hline
\end{tabular}

\begin{tabular}{|c|c|c|c|c|}
\hline Yes & $9(100 \%)$ & $0(0 \%)$ & 9 & \\
\hline Missing & 0 & 1 & 1 & \\
\hline $\begin{array}{l}\text { Leukocyte count } \\
\text {, n (\%) }\end{array}$ & & & & $0.009 *$ \\
\hline$<10,000$ & $36(97 \%)$ & $1(3 \%)$ & 37 & \\
\hline$>=10,000$ & 33 (77\%) & $\begin{array}{r}10 \\
(23 \%)\end{array}$ & 43 & \\
\hline Missing & 0 & 1 & 1 & \\
\hline $\begin{array}{l}\text { Severity of } \\
\text { CDAD, n (\%) }\end{array}$ & & & & 0.041* \\
\hline Mild & 33 (92\%) & $3(8 \%)$ & 36 & \\
\hline Severe & $28(85 \%)$ & $\begin{array}{r}5 \\
(15 \%)\end{array}$ & 33 & \\
\hline Fulminant & $3(100 \%)$ & $0(0 \%)$ & 3 & \\
\hline $\begin{array}{r}\text { Ileum or } \\
\text { megacolon }\end{array}$ & $1(100 \%)$ & $0(0 \%)$ & 1 & \\
\hline Recurrence & $3(43 \%)$ & $\begin{array}{r}4 \\
(57 \%)\end{array}$ & 7 & \\
\hline Missing & 0 & 1 & 1 & \\
\hline Age (yrs) & & & & $0.271 \dagger$ \\
\hline Mean (SD) & $62(19)$ & 68 (17) & $63(19)$ & \\
\hline Range & $13-91$ & $31-91$ & $13-91$ & \\
\hline $\begin{array}{l}\text { Days to } \\
\text { resolution of } \\
\text { fever }\end{array}$ & & & & $0.371 \dagger$ \\
\hline Mean (SD) & $3.8(4.7)$ & $2(2)$ & $3.3(4.2)$ & \\
\hline Range & $0-14$ & 01-Jun & $0-14$ & \\
\hline $\begin{array}{l}\text { Days to } \\
\text { resolution of } \\
\text { diarrhea }\end{array}$ & & & & $0.912 \dagger$ \\
\hline Mean (SD) & $4.7(4.2)$ & $\begin{array}{r}4.8 \\
(4.2)\end{array}$ & $4.7(4.2)$ & \\
\hline Range & 1-17 & $1-15$ & $1-17$ & \\
\hline
\end{tabular}

$\mathrm{SD}=$ Standard deviation

* Fisher's Exact test

† F test

Revista electrónica publicada por el Departamento de Farmacología de la Escuela de Medicina de la Universidad de Costa Rica, 2060 San José, Costa Rica. ${ }^{\circledR}$ All rights reserved. Licensed under a Creative Commons Unported License. (C) (D) $\Theta$ Contáctenos: rev.med.ucr@gmail.com. Tel: (506) 25-11 4492, Fax: 25-11-4489. 
Greater leukocyte count was associated with higher probability of recurrence.

Greater leukocyte count was associated with higher probability of recurrence. The proportion recurred among patients with leukocyte count of $10,000 \times 10^{3} / \mathrm{mm}^{3}$ and above was $23 \%(95 \% \mathrm{CI}$ 12-39), while the same proportion among patients with a count of less than $10,00010^{3} / \mathrm{mm}^{3}$ was $3 \%$ (95\% CI 0.1-14), Fisher's exact p-value $=0.009$.

Severity of diarrhea was also predictive of future recurrence in univariate analyses. Fifteen percent of patients with severe CDAD had a recurrence (95\% CI 5-32) compared to $8 \%$ of recurrence in patients with mild CDAD (95\% CI 222 ), Fisher's exact p-value $=0.04$.

Table 3 associates patient characteristic with the manner in which patients left the CDAD unit, what we call discharge outcome. Neither age nor gender was related to discharge outcome. Among the medical history characteristics we identified, congestive heart failure, use of proton pump inhibitors, and vasopressors were associated with higher probability of death.

Patients with congestive heart failure had significantly higher mortality: 2 out of 4 patients with congestive heart failure died, 50\% (95\% CI 793) compared to $8 \%$ among 77 patients without this co-morbidity (95\% CI 3-16), Fisher's exact pvalue $=0.035$.

Seventeen percent of patients in whom proton pump inhibitors were used died (95\% CI 537) compared to $7 \%$ of patients who did not use this medication (95\% CI 2-18), Fisher's exact pvalue $=0.032$. The use of vasopressors was also associated with higher mortality: $43 \%$ versus $7 \%$ in non-users, 95\% CI 10-82 and 2-15, respectively; $\mathrm{p}$-value $=0.012$.
Table 4 summarizes the results of simple and multivariate linear regressions of the relationship between individual and medical history characteristics and the duration of diarrhea. The final model included patients' age, use of antibiotics, probiotics, and vasopressors, degree of immune suppression, and leukocyte count.

In univariate and multivariate analyses, we observed a change in the relationship of duration of diarrhea and patients' age for older versus younger patients. Among otherwise similar patients age 40 and younger at admission, we estimate that on average, diarrhea lasts $3 \%$ shorter for patients one year older $(95 \%$ CI $0-6$, p-value = $0.024)$. For patients above 40 years of age and having similar medical history characteristics, the diarrhea lasts on average 1\% longer for every 1 year increase in age (95\% CI 0-2, p-value $=0.011)$.

Use of antibiotics (cephalosporins) was associated with reduced duration of diarrhea in univariate and multivariate analyses. Among patients of the same age, same profile of probiotics and/or vasopressor usage, the same degree of immune suppression, and leukocyte count, the use of antibiotics reduced the duration of diarrhea by an estimated 49\% (95\% CI 39-63, p-value < 0.0001).

The use of probiotics and vasopressors, on the other hand, was associated with longer duration of diarrhea. In multivariate analyses, use of probiotics was associated with 2.6-times longer duration of diarrhea in this patient population (95\% CI 1.65-4.02, p-value < 0.0001). Probiotics were generally used in recurrent cases, which could well explain this finding. The use of vasopressors was associated with 3-fold longer duration of diarrhea (95\% CI 2.1-4.5, p-value < 0.0001). The use of vasopressors can be an indicator of septic shock implying increased severity of disease, which may explain this 
association. The model explained about $40 \%$ of the variability in duration of diarrhea in these patients.

Table 3. Relationships of patient characteristics with the outcome

\begin{tabular}{|c|c|c|c|c|}
\hline & Outcome & & & P values* \\
\hline & $\begin{array}{l}\text { Transfer } \\
(\mathrm{N}=20)\end{array}$ & $\begin{array}{c}\text { Discharge } \\
(\mathrm{N}=52)\end{array}$ & $\begin{array}{l}\text { Death } \\
(\mathrm{N}=8)\end{array}$ & $\begin{array}{c}\text { Total } \\
(\mathrm{N}=81)\end{array}$ \\
\hline Gender, n (\%) & & & & $0.547^{*}$ \\
\hline Female & $10(27 \%)$ & $22(59 \%)$ & $5(14 \%)$ & 37 \\
\hline Male & $10(23 \%)$ & $30(70 \%)$ & $3(7 \%)$ & 43 \\
\hline Missing & 0 & 1 & 0 & 1 \\
\hline $\begin{array}{l}\text { Proton pump } \\
\text { inhibitor , n (\%) }\end{array}$ & & & & $0.035 *$ \\
\hline No & $18(33 \%)$ & $32(59 \%)$ & $4(7 \%)$ & 54 \\
\hline Yes & $2(8 \%)$ & $18(75 \%)$ & $(17 \%)$ & 24 \\
\hline Missing & 0 & 3 & 0 & 3 \\
\hline $\begin{array}{l}\text { Antibiotic use in } \\
\text { last } 3 \text { months, } n \\
\text { (\%) }\end{array}$ & & & & 0.100* \\
\hline No & $6(18 \%)$ & $21(64 \%)$ & $6(18 \%)$ & 33 \\
\hline Yes & $14(29 \%)$ & $32(67 \%)$ & $2(4 \%)$ & 48 \\
\hline $\begin{array}{l}\text { Current } \\
\text { antibiotic use , n } \\
\text { (\%) }\end{array}$ & & & & $0.584 *$ \\
\hline No & $11(30 \%)$ & $22(59 \%)$ & $4(11 \%)$ & 37 \\
\hline Yes & $9(20 \%)$ & $31(70 \%)$ & $4(9 \%)$ & 44 \\
\hline $\begin{array}{l}\text { Cephalosporins, } \\
\text { n (\%) }\end{array}$ & & & & $0.309^{*}$ \\
\hline No & $16(28 \%)$ & 37 (65\%) & $4(7 \%)$ & 57 \\
\hline Yes & $4(17 \%)$ & $16(67 \%)$ & $4(17 \%)$ & 24 \\
\hline $\begin{array}{l}\text { Quinolones, n } \\
\text { (\%) }\end{array}$ & & & & $0.236^{*}$ \\
\hline No & $16(22 \%)$ & $49(67 \%)$ & $8(11 \%)$ & 73 \\
\hline
\end{tabular}

\begin{tabular}{|l|l|l|l|l|}
\hline Yes & $4(50 \%)$ & $4(50 \%)$ & $0(0 \%)$ & $\mathbf{8}$ \\
\hline $\begin{array}{l}\text { Penicillins, n } \\
\text { (\%) }\end{array}$ & & & & $\mathbf{1 . 0 0 0}$ \\
\hline No & $19(25 \%)$ & $48(64 \%)$ & $8(11 \%)$ & $\mathbf{7 5}$ \\
\hline Yes & $1(17 \%)$ & $5(83 \%)$ & $0(0 \%)$ & $\mathbf{6}$ \\
\hline $\begin{array}{l}\text { Clindamycin, n } \\
\text { (\%) }\end{array}$ & & & & $\mathbf{0 . 4 5 1}$ \\
\hline No & $20(26 \%)$ & $48(63 \%)$ & $8(11 \%)$ & $\mathbf{7 6}$ \\
\hline Yes & $0(\%)$ & $5(100 \%)$ & $0(0 \%)$ & $\mathbf{5}$ \\
\hline $\begin{array}{l}\text { Carbapenems, n } \\
\text { (\%) }\end{array}$ & $19(24 \%)$ & $52(66 \%)$ & $8(10 \%)$ & $\mathbf{7 9}$ \\
\hline No & $1(50 \%)$ & $1(50 \%)$ & $0(0 \%)$ & $\mathbf{2}$ \\
\hline Yes & $16(28 \%)$ & $34(60 \%)$ & $7(12 \%)$ & $\mathbf{5 7}$ \\
\hline $\begin{array}{l}\text { Aminoglycosides } \\
\text { n (\%) }\end{array}$ & $\mathbf{4 ( 1 7 \% )}$ & $\mathbf{1 9}(\mathbf{7 9 \% )}$ & $\mathbf{1}(\mathbf{4} \%)$ & $\mathbf{2 4}$ \\
\hline No & $20(26 \%)$ & $49(64 \%)$ & $7(9 \%)$ & $\mathbf{7 6}$ \\
\hline Yes & $4(80 \%)$ & $1(20 \%)$ & $\mathbf{5}$ \\
\hline Yther, n (\%) & & & $\mathbf{0 . 3 7 5 *}$ \\
\hline No & & & & \\
\hline \hline
\end{tabular}

$\mathrm{SD}=$ Standard deviation

* Fisher's Exact test

$\dagger \mathrm{F}$ test

Due to missing data on leukocyte count, immune suppression, vasopressors, and use of probiotics, the final model included 68 out of a total of 81 subjects. After the data on missing predictors was imputed using a multiple imputation technique, the effects of antibiotics (cephalosporins) and use of probiotics remained statistically significant with only slight attenuation of the regression coefficients towards the null. 
Table 4. Results of simple and multivariate linear regressions estimating the relationship between patients' characteristics and duration of diarrhea

\begin{tabular}{|c|c|c|c|c|}
\hline Characteristic & $\begin{array}{l}\text { Unadjusted } \\
\text { coefficients } \\
\text { from } \\
\text { simple } \\
\text { linear } \\
\text { models }\end{array}$ & & & \\
\hline & $\begin{array}{l}\text { Exponentiated } \\
\text { Coefficient }\end{array}$ & $\begin{array}{c}\mathrm{P}- \\
\text { value }\end{array}$ & $\begin{array}{c}95 \% \\
\text { Confidence } \\
\text { Interval }\end{array}$ & \\
\hline $\begin{array}{l}\text { Age: Slope for } \\
\text { patients } 40 \\
\text { years of age } \\
\text { and younger }\end{array}$ & 0.99 & 0.374 & 0.95 & 1.02 \\
\hline $\begin{array}{l}\text { Age: Slope for } \\
\text { patients older } \\
\text { than } 40\end{array}$ & 1.01 & 0.184 & 1.00 & 1.02 \\
\hline $\begin{array}{l}\text { Use of } \\
\text { cephalosporins }\end{array}$ & 0.68 & 0.046 & 0.46 & 0.99 \\
\hline $\begin{array}{l}\text { Leukocyte } \\
\text { count } 10,000 \\
\text { and greater }\end{array}$ & 1.39 & 0.086 & 0.95 & 2.02 \\
\hline $\begin{array}{l}\text { Use of } \\
\text { probiotics }\end{array}$ & 3.10 & 0.001 & 1.61 & 5.94 \\
\hline $\begin{array}{l}\text { Use of } \\
\text { vasopressors }\end{array}$ & 1.72 & 0.169 & 0.79 & 3.72 \\
\hline \multirow{3}{*}{$\begin{array}{l}\text { Immune } \\
\text { suppression }\end{array}$} & 1.10 & 0.754 & 0.59 & 2.06 \\
\hline & $\begin{array}{c}\text { Adjusted } \\
\text { coefficients } \\
\text { from } \\
\text { multivariate } \\
\text { linear model }\end{array}$ & & & \\
\hline & $\begin{array}{l}\text { Exponentiated } \\
\text { Coefficient }\end{array}$ & $\begin{array}{c}\mathrm{P}- \\
\text { value }\end{array}$ & $\begin{array}{c}95 \% \\
\text { Confidence } \\
\text { Interval }\end{array}$ & \\
\hline $\begin{array}{l}\text { Age: Slope for } \\
\text { patients } 40 \\
\text { years of age } \\
\text { and younger }\end{array}$ & 0.97 & 0.024 & 0.94 & 1.00 \\
\hline $\begin{array}{l}\text { Age: Slope for } \\
\text { patients older } \\
\text { than } 40\end{array}$ & 1.01 & 0.011 & 1.00 & 1.02 \\
\hline $\begin{array}{l}\text { Use of } \\
\text { cephalosporins }\end{array}$ & 0.51 & 0.000 & 0.37 & 0.71 \\
\hline $\begin{array}{l}\text { Leukocyte } \\
\text { count } 10,000\end{array}$ & 1.41 & 0.068 & 0.97 & 2.05 \\
\hline
\end{tabular}

\begin{tabular}{|l|c|c|c|c|}
\hline and greater & & & & \\
\hline $\begin{array}{l}\text { Use of } \\
\text { probiotics }\end{array}$ & 2.58 & 0.000 & 1.65 & $\mathbf{4 . 0 2}$ \\
\hline $\begin{array}{l}\text { Use of } \\
\text { vasopressors }\end{array}$ & 3.06 & 0.000 & 2.09 & $\mathbf{4 . 4 8}$ \\
\hline $\begin{array}{l}\text { Immune } \\
\text { suppression }\end{array}$ & 1.61 & 0.103 & 0.91 & $\mathbf{2 . 8 5}$ \\
\hline $\begin{array}{c}\text { Number of } \\
\text { observations }\end{array}$ & 68 & & & \\
\hline \hline $\begin{array}{c}\text { Model R- } \\
\text { Squared }\end{array}$ & $\mathbf{0 . 4 1}$ & & & \\
\hline
\end{tabular}

Figure 4. Relationship between duration of diarrhea and age of patients

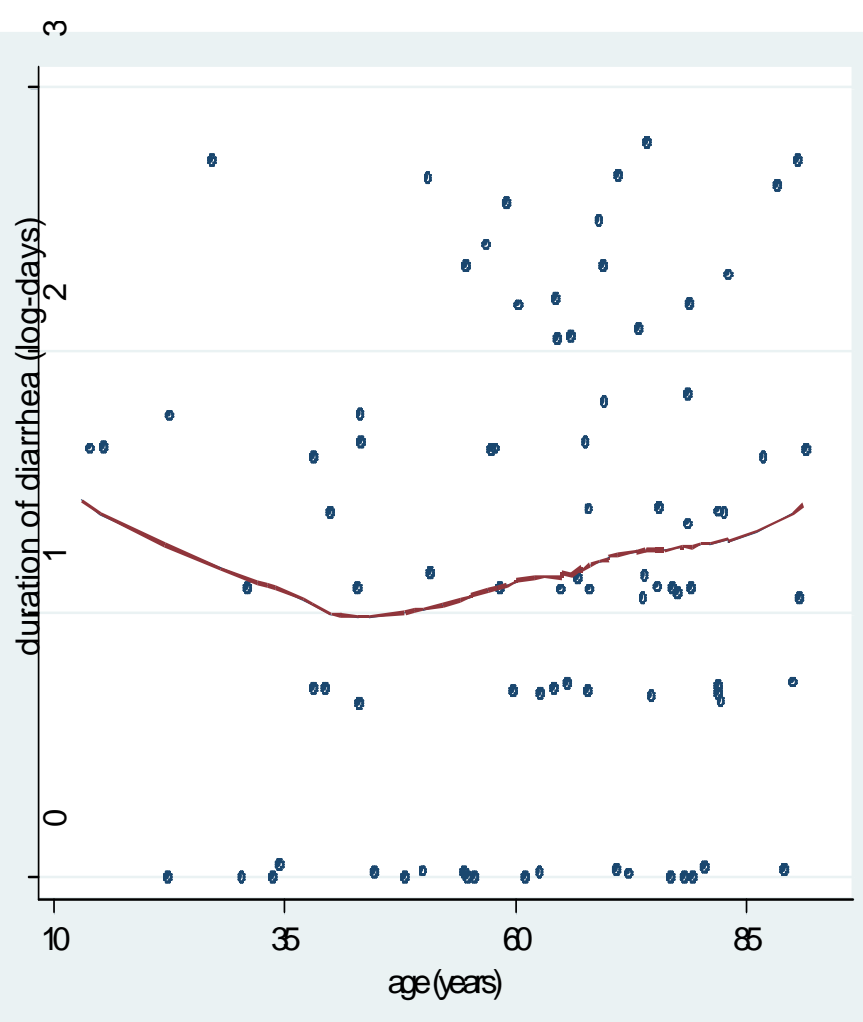

Revista electrónica publicada por el Departamento de Farmacología de la Escuela de Medicina de la Universidad de Costa Rica, 2060 San José, Costa Rica. ${ }^{\circledR}$ All rights reserved. Licensed under a Creative Commons Unported License. 


\section{DISCUSSION}

This is, to our knowledge, the first report of a nosocomial outbreak of hypervirulent CDAD in a developing country. Previous reports of nosocomial CDAD have been from developed countries. However, given the increasing prevalence of CDAD globally, due to aging populations and hospital crowding [19], the frequency of these outbreaks may rise. Thus, an epidemiological study of the global spread of hypervirulent $C$. difficile may be warranted.

This study was limited by available diagnostics. The only laboratory-based test available in the hospital was ELISA for toxin A in stool. As a result, cases of CDAD not producing detectable levels of toxin $A$ would have been missed. The study reports data for the first four months that the CDAD unit was in operation, although the unit operated beyond August 2009. The ability to collect data for longer periods of time and to include more patients could alter the results for overall mortality and recurrence, as well as impact the statistics on discharge outcome and duration of diarrhea.

It would have been informative to follow CDAD patients after they were discharged from the isolation unit and the hospital. This type of epidemiologic follow up should be part of all hypervirulent outbreak management protocols in order to follow and document trends and detect emergent ATB-resistant strains. This type of data recollection might prevent subsequent nosocomial and community outbreaks.

Despite these limitations, the management of this outbreak provides a model for managing similar outbreaks, especially in hospitals in locations with limited public health and healthcare resources. The integrated management and infection control program resulted in better than average outcomes, indicating that outbreaks of this nature need not be more lethal in a developing country compared to a developed country $[20,21,22]$.

In conclusion, for effective control of this disease, a prompt and rigorous response, strict sterilization and containment, and cost-effective treatments are more important than access to complex infrastructure or advanced support services.

\section{Acknowledgments}

We would like to acknowledge and thank the Department of Biostatistics at Johns Hopkins Bloomberg School of Public Health for their valuable help with the statistical analysis of this article.

\section{REFERENCES}

1. Gerding DN, Johnson S, Peterson LR, Mulligan ME, Silva J Jr. Clostridium difficile-associated diarrhea and colitis. Infect Control Hosp Epidemiol 1995; 16: 459-77.

2. Kim KH, Fekety R, Batts DH, Brown D, Cudmore M, Silva J $\mathrm{Jr}$, et al. Isolation of Clostridium difficile from the environment and contacts of patients with antibioticassociated colitis. J Infect Dis 1981; 143: 42-50.

3. Hookman P, Barkin JS. Clostridium difficile associated infection, diarrhea and colitis. World J Gastroenterol 2009; 15: 1554-80.

4. Pépin J, Saheb N, Coulombe MA, Alary ME, Corriveau MP, Authier S, et al. Emergence of fluoroquinolones as the predominant risk factor for Clostridium difficile-associated diarrhea: a cohort study during an epidemic in Quebec. Clin Infect Dis 2005; 41: 1254-60.

5. Loo VG, Poirier L, Miller MA, et al. A predominantly clonal multi-institutional outbreak of Clostridium difficile 
associated diarrhea with high morbidity and mortality. N Engl J Med 2005 ; 353 (23) :2442-9.

6. Hookman P, Barkin JS. Review: Clostridium difficileassociated disorders-diarrhea and Clostridium difficile colitis: the emergence of a more virulent era. Dig Dis Sci 2007;52:1071.

7. Hookman P, Barkin JS. Guidelines for prevention, surveillance, diagnosis and treatment in this new era of more virulent strains of antibiotic-associated diarrhea (AAD), Clostridium difficile- associated diarrhea (CDAD) and Clostridium difficile colitis (CDAC). Pract Gastroenterol 2006; 30: 65-82.

8. Loo VG, Libman MD, Miller MA, Bourgault AM, Frenette $\mathrm{CH}$, Kelly M, et al. Clostridium difficile: a formidable foe. CMAJ 2004; 171: 47-48.

9. Warny M, Pepin J, Fang A, Killgore G, Thompson A, Brazier $\mathrm{J}$, et al. Toxin production by an emerging strain of Clostridium difficile associated with outbreaks of severe disease in North America and Europe. Lancet 2005; 366: 1079-84.

10. Kuijper EJ, Barbut F, Brazier JS, Kleinkauf N, Eckmanns T, Lambert ML, et al. Update of Clostridium difficile infection due to PCR ribotype 027 in Europe, 2008. Euro Surveill 2008; 13: 1-7.

11. Kelly CP, LaMont JT. Clostridium difficile-more difficult than ever. N Engl J Med 2008; 359: 1932-40.

12. Kelly CP. A 76-year-old man with recurrent Clostridium difficile-associated diarrhea: Review of $C$ difficile infection. JAMA 2009; 301: 954-62.

13. Monaghan T, Boswell T, Mahida R. Recent advances in Clostridium difficile-associated disease. Postgrad Med J 2009; 85: 152-162.

14. Lavallee C, Laufer B, Pepin J, Mitchell A, Dubé S, Labbé AC. Fatal Clostridium difficile enteritis caused by B1/NAP1/027 strain: a case series of ileal $C$ difficile infections. Clin Microbiol Infect 2009; 15: 1093-99.

15. Denève C, Janoir C, Poilane I, Fantinato C, Collignon A. New trends in Clostridium difficile virulence and pathogenesis. Int J Antimicrob Agents 2009; 33 Suppl 1: S24-28.
16. Harrell FE Jr. Regression modeling strategies: with applications to linear models, logistic regression, and survival analysis. New York: Springer; 2001.

17. Harrell FE Jr, Lee KL, Pollock BG. Regression models in clinical studies: determining relationships between predictors and response. J Natl Cancer Inst 1988; 80: 1198-202.

18. Allison PD. Missing Data: Quantitative applications in the social sciences. Thousand Oaks (CA): Sage Publications; 2002.

19. Pepin J, Valiquette L, Cossette B. Mortality attributable to nosocomial Clostridium difficile-associated disease during and epidemic caused by a hypervirulent strain in Quebec. CMAJ 2005; 173: 1037-42.

20. Coia JE. What is the role of antimicrobial resistance in the new epidemic of Clostridium difficile? Int J Antimicrob Agents 2009; 33 Suppl1: S9-12.

21.Bartlett JG. Narrative review: the new epidemic of Clostridium difficile-associated enteric disease. Ann Intern Med 2006; 145: 758-64.

22. Miller M, Gravel D, Mulvey M, Taylor G, Boyd D, Simor A, et al. Health care-associated Clostridium difficile infection in Canada: patient age and infecting strain type are highly predictive of severe outcome and mortality. Clin Infect Dis 2010;50:194-201.

\section{Correspondencia:}

M. Cecilia Monge, MD, MPH

Departamento de Medicina Interna

Hospital San Juan de Dios

Avenida 14, calles 6 y 7, Paseo Colon

San José, Costa Rica, 522-1000

Tel.:(506) 8872-05-32,Fax: 50622280551

ceciliamonge4@yahoo.com 